Syntax Literate : Jurnal Ilmiah Indonesia p-ISSN: 2541-0849 e-ISSN: 2548-1398

Vol. 5, No. 5 Mei 2020

\title{
DETERMINAN KUALITAS LAPORAN KEUANGAN PEMERINTAH DAERAH KOTA SUKABUMI
}

\section{Zulkarnain dan Dahlia Anggyastuti Ningrum}

Program Studi Akuntansi, Institut Manajemen Wiyata Indonesia

Email: zulkarnain@imwi.ac.id dan dahliaanggi31@gmail.com

\section{Abstract}

Government financial statements are essentially a form of government accountability to the people for managing public funds. The government must arrange financial statements until fulfill the qualitative characteristics of financial statements that are relevant, reliable, comparable and understandable. This research aims to examine the determinants of the quality of financial statements, including human resource competencies, the application of regional financial accounting information systems, and the application of government accounting standards in the Regional Government of Sukabumi City. Data collection was done through survey techniques in 19 OPDs in the form of Agencies and Offices in Sukabumi City Regional Government with a research instrument in the form of a questionnaire. Questionnaires were distributed to respondents, namely the Finance Sub-Staff in each OPD of 40 people. Testing of research instruments is done through validity and reliability testing. Testing the fulfillment of classic requirements/assumptions is done through normality test, multicollinearity test, and heteroscedasticity test. Hypothesis testing is done by using multiple regression analysis: coefficient of determination test, $F$ test and t test with SPSS program tools. The results showed that partially human resource competence did not affect the quality of the financial statements of the Sukabumi City Government. At present the Regional Government of Sukabumi City has qualified financial reports, at a time when human resource competencies were inadequate due to lack of training in accountancy. The financial statements in this case are arranged in collaboration with external partners. On the other hand, the application of regional financial accounting information systems and the application of government accounting standards partially has a significant positive effect on the quality of the Sukabumi City Government's financial statements. The quality of the information processing that is supported by the quality of the information system helps in producing good financial reports. The implementation of government accounting standards increases the credibility, transparency and accountability of regional financial management. The result of this research also showed that simultaneously the three determinants have a significant positive effect on the quality of the financial statements of the Sukabumi City Government with the results of the coefficient of determination testing showing the ability to explain variations of $81.5 \%$.

Keywords: Quality of Regional Government Financial Statement, Human Resourches Competencies, Regional Financial Accounting Information Systems, Government Accountancy Standards. 


\section{Abstrak}

Laporan keuangan pemerintah pada hakikatnya merupakan suatu bentuk pertanggungjawaban pemerintah kepada rakyat atas pengelolaan dana publik. Pemerintah wajib menyusun laporan keuangan hingga memenuhi ciri kualitatif laporan keuangan yaitu relevan, cakap, bisa di perhitungkan serta bisa dimengerti. Penelitian ini dilakukan supaya bisa menilai determinan kualitas laporan keuangan, diantaranya kemampuan sumber daya manusia, implementasi sistem informasi akuntansi keuangan daerah, dan implementasi standar akuntansi pemerintahan pada Pemerintah Daerah Kota Sukabumi. Pengumpulan data dilakukan melalui teknik survey pada 19 OPD berbentuk Badan dan Dinas di lingkungan Pemerintah Daerah Kota Sukabumi dengan instrumen penelitian berupa kuesioner. Kuesioner disebarkan kepada responden yaitu Staf Sub Bagian Keuangan pada masing-masing OPD yang berjumlah 40 orang. Pengujian instrumen penelitian dilakukan melalui uji validitas dan uji reliabilitas. Pengujian pemenuhan syarat/ asumsi klasik dilakukan melalui uji normalitas, uji multikolinearitas, dan uji heteroskedastisitas. Pengujian hipotesis dilakukan dengan menggunakan analisis regresi berganda: uji koefisien determinasi, uji $\mathrm{F}$ dan uji t dengan alat bantu program SPSS. Hasil penelitian memperlihatkan bahwa dengan cara parsial kemampuan sumber daya manusia tidak berdampak kepada kualitas laporan keuangan Pemerintah Daerah Kota Sukabumi. Saat ini Pemerintah Daerah Kota Sukabumi telah memiliki laporan keuangan yang berkualitas, di saat kemampuan sumber daya manusia belum memadai akibat kurangnya pelatihan dalam bidang akuntansi. Laporan keuangan dalam hal ini disusun bekerjasama dengan mitra eksternal. Di sisi lain, penerapan sistem informasi akuntansi keuangan daerah serta implementasi standar akuntansi pemerintahan secara parsial berpengaruh positif signifikan terhadap kualitas laporan keuangan Pemerintah Daerah Kota Sukabumi. Kualitas proses pengolahan informasi yang didukung oleh kualitas sistem informasi membantu dalam menghasilkan laporan keuangan yang baik. Penerapan standar akuntansi pemerintahan meningkatkan kredibilitas, transparansi, dan akuntabilitas pengelolaan keuangan daerah. Hasil penelitian ini juga memperlihatkan bahwa dengan cara simultan ketiga determinan tersebut berdampak positif signifikan kepada kualitas laporan keuangan Pemerintah Daerah Kota Sukabumi dengan hasil pengujian koefisien determinasi menunjukkan kemampuan menjelaskan variasi sebesar 81,5\%.

Kata kunci: kualitas laporan keuangan pemerintah daerah, kompetensi SDM, sistem informasi akuntansi keuangan daerah, standar akuntansi pemerintahan.

\section{Pendahuluan}

Reformasi birokrasi merupakan upaya berkelanjutan yang setiap tahapannya memberikan perubahan atau perbaikan birokrasi ke arah yang lebih baik. Dengan adanya reformasi diharapkan dapat diwujudkan organisasi yang baik, bersih, tertata, tanpa adanya kolusi dan nepotisme (Lusiawati, 2020).

Reformasi menggulirkan sistem pemerintahan yang baru, disebut otonomi daerah. Daerah diberikan kewenangan (authority) untuk mengatur serta mengurus sendiri daerahnya (Edy Sutrisno, Widhi Novianto, Ani Suprihartini \& Rita Dwi KU, 2015). Makna mengatur ialah melahirkan kebijakan atau peraturan dengan mempertimbangkan kepentingan masyarakat berlandaskan pada adat dan kebudayaan atau kearifan lokal, 
selanjutnya makna mengurus ialah menyediakan layanan untuk memenuhi kebutuhan masyarakat.

Dalam melakukan kebijakan daerah diharapkan daerah bisa mandiri dalam mengelola keuangan daerah. Kemandirian terwujud dalam bentuk kemampuan membiayai sendiri seluruh kegiatan pemerintah daerah, berupa pemberian layanan yang optimal kepada masyarakat dan pembangunan. Sumber penerimaan daerah dapat diperoleh diantaranya dari pajak daerah dan retribusi daerah yang dibayarkan oleh masyarakat (Briando, 2017).

Pada setiap akhir tahun anggaran, kepala daerah wajib menyampaikan laporan pengelolaan pemerintahan daerah terhadap pemerintah pusat dan memberikan informasi laporan penyelenggaraan pemerintahan daerah tersebut kepada masyarakat (INDONESIA, n.d.). Hal ini sebagai bentuk pertanggungjawaban pemerintah daerah kepada masyarakat didasarkan pada hubungan keagenan masyarakat selaku principal serta pemerintah daerah sebagai agent. Laporan penyelenggaraan pemerintah daerah dapat berupa laporan kinerja dan/atau informasi keuangan pemerintah daerah.

Jensen serta Meckling (1976) mengartikan ikatan keagenan selaku sebuah kontrak antara principal dengan agent, dengan melihat pendelegasian beberapa wewenang pengambilan keputusan dari principal kepada agent. Sebagai agent, pemerintah daerah melaksanakan wewenang yang sudah diserahkan pada pemerintah pusat. Pemerintah daerah juga harus mempertanggungjawabkan tugasnya kepada masyarakat untuk memaksimalkan kesejahteraan mereka (Zelmiyanti, 2016).

Laporan keuangan disusun untuk memberikan gambaran informasi tentang posisi aset, kewajiban dan ekuitas yang terjadi dalam pemerintahan daerah pada suatu periode tertentu dan rangkuman dari transaksi-transaksi keuangan yang sudah terjadi semasa tahun buku yang bersangkutan (Munawir et al., 2010). Salah satu ketentuan dalam Undang-Undang tentang Keuangan Negara mewajibkan penggunaan Standar Akuntansi Pemerintahan selaku basis penyusunan laporan keuangan bagi instansi pemerintah (Indonesia, 2004).

Informasi akuntansi yang tersaji di dalam laporan keuangan pemerintah daerah mesti mencukupi sejumlah ciri kualitatif sebagaimana dipersyaratkan dalam Peraturan Pemerintah No. 71 Tahun 2010 mengenai Standar Akuntansi Pemerintahan, yaitu relevan, cakap, bisa dibandingkan serta bisa dimengerti. Informasi disebut relevan jika bisa memengaruhi pengambilan keputusan manajerial. Informasi yang relevan bisa dipakai untuk menilai kejadian pada masa lampau, masa sekarang, dan masa depan (predictive value), dan memperjelaskan serta memperbaiki maksud yang telah dibuat sebelumnya (feedback value). Agar informasi dikatakan relevan, informasi mesti ada sesuai waktu bagi pengguna informasi atau untuk pengambilan keputusan (timeliness) (Indonesia, 2010).

Karakteristik kualitatif berikutnya yaitu keandalan sangat berkaitan terhadap kompentisa suatu informasi dalam menyediakan dengan wajar kondisi serta peristiwa yang disediakan sesuai kondisi yang sebenarnya terjadi. Suatu informasi disebut cakap 
jika: (1) Dapat diuji kebenarannya (verifiabel); (2) Netral, tidak ada unsur bias dalam penyajian laporan atau informasi keuangan. (3) Penyajian secara wajar/ jujur (representational faithfulness) yang menggambarkan keadaan secara wajar dan lengkap menunjukkan hubungan antara data akuntansi dan peristiwa-peristiwa yang sebenarnya digambarkan oleh data tersebut (Indonesia, 2010).

Karakteristik dapat dibandingkan memiliki makna suatu informasi dikatakan memiliki manfaat apabila informasi tersebut dapat diperbandingkan, baik antar periode maupun antar entitas. Dapat dipahami artinya suatu informasi dikatakan bermanfaat apabila dapat dengan mudah dipahami oleh pengguna dan dinyatakan dalam bentuk serta istilah yang disesuaikan dengan batas pemahaman pengguna (Indonesia, 2010).

Apabila informasi yang tersaji di dalam informasi keuangan pemerintah daerah mencukupi ciri kualitatif laporan keuangan tersebut, berarti pemerintah daerah sanggup mewujudkan kualitas laporan keuangan yang baik dalam pengurusan keuangan daerah. Apabila tidak dapat dipenuhi sebagaimana ketentuan perundang-undangan, maka akan berpotensi mengakibatkan kerugian daerah, kekurangan penerimaan daerah, kekurangan administrasi, ketidakhematan, ketidakefisienan, dan ketidakfektifan (Roviyantie, 2011).

Laporan Keuangan Pemerintah Daerah (LKPD) setiap tahunnya akan memperoleh penilaian berupa pendapat dari Badan Pemeriksa Keuangan (BPK). Saat BPK menyerahkan pendapat Wajar Tanpa Pengecualian (WTP) terhadap Laporan Keuangan, ini berarti organisasi tersebut telah menyajikan dan mengungkapkan informasi keuangan secara wajar dan berkualitas (Erviana, 2017). Rendahnya kualitas laporan keuangan bisa diakibatkan oleh belum diterapkannya sistem informasi akuntansi keuangan daerah serta kurangnya pemahaman akuntansi dari penyusun laporan keuangan itu sendiri serta kurangnya kemampuan sumber daya manusia yang dimiliki. Hal ini terkait kemampuan untuk melakukan tugas serta tanggung jawab yang diserahkan kepadanya dengan bekal pendidikan, pelatihan serta pengalaman yang cukup memenuhi.

Penelitian oleh (Khalid, 2016) menyatakan bahwa kemampuan sumber daya manusia berdampak positif kepada kualitas laporan keuangan pemerintah daerah (Khalid, 2016). Penerapan sistem informasi akuntansi keuangan daerah juga berdampak positif terhadap kualitas pelaporan keuangan daerah (Eriotis et al., 2011). Demikian juga penelitian yang dilakukan oleh (Lasoma, 2013) yang menemukan bahwa penetapan standar akuntansi pemerintahan berdampak positif terhadap kualitas laporan keuangan daerah (Lasoma, 2013).

Penelitian ini akan dilakukan di Pemerintah Daerah Kota Sukabumi dengan alasan untuk mendapat predikat opini audit Wajar Tanpa Pengecualian (WTP), Pemerintah Daerah Kota Sukabumi harus menunggu sekian tahun lamanya, dan baru pada beberapa tahun terakhir semenjak tahun 2014 Pemerintah Daerah Kota Sukabumi mendapatkan opini WTP tersebut. Penelitian ini bertujuan untuk menguji determinan kualitas laporan keuangan, diantaranya kemapuan sumber daya manusia, penetapan sistem informasi akuntansi keuangan daerah, dan penerapan standar akuntansi pemerintahan pada Pemerintah Daerah Kota Sukabumi. 


\section{Metode Penelitian}

Populasi dalam penelitian ini adalah seluruh staf Sub Bagian Keuangan (yang berkaitan langsung dengan pengelolaan keuangan) di Organisasi Perangkat Daerah (OPD) di lingkungan Pemerintah Daerah Kota Sukabumi. Teknik penarikan sampel adalah purposive sampling, yaitu terbatas pada OPD berbentuk Badan dan Dinas, serta yang telah menerapkan Standar Akuntansi Pemerintahan (SAP) berbasis akrual.

Sumber data yang digunakan adalah data primer, yaitu data yang dikumpulkan langsung dari hasil pengisian kuesioner oleh responden staf Sub Bagian Keuangan. Definisi operasional variabel dan indikator pengukuran variabel sebagai berikut:

a. Kualitas laporan keuangan pemerintah daerah yaitu variabel dependen (Y), didefinisikan sebagaimana PP No. 71 Tahun 2010 yang menuturkan, untuk memperoleh informasi keuangan yang memberi manfaat bagi para penggunanya, oleh karena itu informasi yang ada dalam laporan tersebut mesti berkualitas serta berguna dalam pengambilan keputusan. Indikator pengukuran variabel diantaranya relevan, andal, dapat dibandingkan dan dapat dipahami.

b. Kompetensi sumber daya manusia yaitu variabel independen $\left(\mathrm{X}_{1}\right)$, didefinisikan sebagai kemampuan sumber daya manusia untuk melaksanakan tugasnya sesuai dengan bekal pendidikan, pelatihan serta pengalaman. Sumber daya manusia yang terampil lebih mudah dimerngerti akuntansi dengan baik, oleh karenanya dalam melaksanakan kewajibannya bisa dilaksanakannya dengan cara cermat serta sesuai waktu dalam mempersebahkan laporan keuangan. Indikator pengukuran variabel diantaranya pendidikan, pelatihan, dan pengalaman.

c. Penerapan sistem informasi akuntansi keuangan daerah yaitu variabel independen $\left(\mathrm{X}_{2}\right)$, didefinisikan dengan tersedianya sistem informasi yang memadai, terintegrasi dan mudah digunakan, serta mampu mengolah dan menyediakan data yang akurat dan terkini dalam kaitannya menunjang proses penyusunan laporan keuangan pemerintah daerah (Sari \& Witono, 2014). Indikator pengukuran variabel diantaranya sistem layanan, kualitas sistem, dan kualitas informasi.

d. Penerapan standar akuntansi pemerintahan (SAP) yaitu variabel independen $\left(\mathrm{X}_{3}\right)$, didefinisikan dengan diterapkannya prinsip-prinsip akuntansi sebagaimana PP No.71 tahun 2010 dalam menyusun dan menyajikan laporan keuangan pemerintah. Indikator pengukuran variabel diantaranya basis akrual, anggaran berbasis kas, penyajian CALK, pengakuan persediaan, pengakuan investasi, pengukuran aset tetap, perlakuan akuntansi konstruksi, pengakuan kewajiban, perlakuan akuntansi koreksi kesalahan, dan konsep penyajian laporan keuangan konsolidasi.

Analisis data yang dilakukan diantaranya pengujian kualitas instrumen melalui uji validitas dan uji reliabilitas; pengujian pemenuhan syarat/asumsi klasik melalui uji normalitas, uji multikolinearitas, dan uji heteroskedastisitas; serta pengujian hipotesis 
dengan menggunakan analisis regresi linier berganda: uji koefisien determinasi, uji t dan uji F dengan alat bantu program SPSS.

\section{Hasil dan Pembahasan}

\section{A. Hasil Penelitian}

\section{Hasil Pengujian Kualitas Instrumen}

Uji validitas dilakukan untuk mengukur sah ataupun valid tidaknya suatu kuesioner. Kuesioner diuangkapkan valid apabila pertanyaan terhap kuesioner bisa untuk mengatakan sesuatu yang akan diukur oleh kuesioner tersebut. Pengujian memakai uji dua sisi dengan tingkat signifikansi 0,05. Kriteria pengujian adalah jika $r$ hitung $\geq r$ tabel, oleh karena itu instrumen ataupun itemitem pernyataan berkorelasi signifikan kepada skor total (dinyatakan valid) (Arikunto, 2016). Uji validitas dilakukan terhadap semua butir pertanyaan (Variabel Kompetensi Sumber Daya Manusia $\left(\mathrm{X}_{1}\right), 5$ item; Variabel Penerapan Sistem Informasi Akuntansi Keuangan Daerah $\left(\mathrm{X}_{2}\right), 6$ item; Variabel Penerapan Standar Akuntansi Pemerintahan $\left(\mathrm{X}_{3}\right), 11$ item; dan Variabel Kualitas Laporan Keuangan Pemerintah Daerah (Y), 11 item). Hasil pengolahan data menunjukkan bahwa semua butir pertanyaan menghasilkan nilai $r$ hitung $\geq r$ tabel. Dapat disimpulkan bahwa semua pertanyaan dalam kuesioner dinyatakan valid atau layak digunakan untuk mengungkapkan sesuatu yang akan diukur.

Uji reliabilitas dilakukan untuk mengetahui seberapa jauh pengukuran dapat memberikan hasil yang tidak berbeda jika dilakukan pengukuran kembali terhadap subjek yang sama. Dengan kata lain uji reliabilitas merupakan kriteria tingkat kemantapan atau konsisten suatu alat ukur (kuesioner). Pengujian dilakukan dengan metode Cronbach's Alpha. Nilai alpha antara 0,8 sampai dengan 1 dikategorikan sebagai reliabilitas baik, nilai alpha antara 0,6 sampai 0,79 dikategorikan sebagai reliabilitas diterima, dan nilai alpha kurang dari 0,6 dikategorikan sebagai reliabilitas kurang baik (Arikunto, 2016). Hasil perhitungan menunjukan bahwa nilai Cronbach' Alpha untuk setiap variabel adalah lebih dari 0,70. Dengan demikian dapat disimpulkan bahwa pertanyaan untuk masing-masing variabel dikatakan reliabel.

\section{Hasil Pengujian Pemenuhan Syarat/Asumsi Klasik}

\section{a. Hasil uji normalitas}

Uji normalitas digunakan untuk menguji apakah data terdistribusi normal. Pengujian dapat dilakukan dengan menggunakan uji Kolmogorov Smirnov. Data dianggap terdistribusi normal bila nilai signifikansi lebih besar dari 0,05 (Sugiyono, 2017). Berikut ini hasil uji normalitas dimaksud: 
Tabel 2

Hasil Uji Normalitas

One-Sample Kolmogorov-Smirnov Test

\begin{tabular}{llr}
\hline & & \multicolumn{2}{c}{ Unstandardized } \\
& & Residual \\
\hline $\mathrm{N}$ & Mean & .0000000 \\
\cline { 2 - 3 } Normal Parameters & Std. Deviation & 2.59832153 \\
\hline Most Extreme Differences & Absolute & .137 \\
\cline { 2 - 3 } & Positive & .075 \\
\cline { 2 - 3 } & Negative & -.137 \\
\hline \multicolumn{1}{c}{ Test Statistic } & & .137 \\
\hline Asymp. Sig. (2-tailed) & & $.057^{\mathrm{c}}$ \\
\hline a. Test distribution is Normal. & & \\
b. Calculated from data. & & \\
c. Lilliefors Significance Correction. & \\
Sumber: Data diolah (2019) & &
\end{tabular}

Berdasarkan tabel 2 di atas, nilai signifikansi Asymp. Sig. (2-tailed) sebesar 0,057 >0,05, maka memenuhi kriteria data telah terdistribusi normal.

\section{b. Hasil uji multikolinearitas}

Uji multikolinearitas dilakukan bertujuan untuk menguji apakah model regresi ditemukan adanya korelasi atau hubungan antar variabel independen. Model regresi dikatakan baik apabila tidak terjadi multikolinearitas. Terjadi multikolinearitas apabila nilai tolerance lebih kecil dari 0.10 dan nilai VIF lebih besar dari 10 (Sugiyono, 2017).

Hasil uji multikolinearitas dapat dilihat pada tabel berikut:

Tabel 3

Hasil Uji Multikolinearitas

\begin{tabular}{lccc}
\hline \multicolumn{1}{c}{ Nama Variabel } & Tolerance & VIF & keterangan \\
\hline $\begin{array}{l}\text { Kompetensi Sumber } \\
\text { Daya Manusia }\left(\mathrm{X}_{1}\right)\end{array}$ & 0,861 & 1.162 & $\begin{array}{c}\text { Tidak terjadi } \\
\text { multikolinearitas }\end{array}$ \\
\hline $\begin{array}{l}\text { Penerapan Sistem } \\
\text { Informasi Akuntansi } \\
\text { Keuangan Daerah }\left(\mathrm{X}_{2}\right)\end{array}$ & 0,434 & 2.307 & $\begin{array}{c}\text { Tidak terjadi } \\
\text { multikolinearitas }\end{array}$ \\
\hline $\begin{array}{l}\text { Penerapan Standar } \\
\text { Akuntansi Pemerintah } \\
\left(\mathrm{X}_{3}\right)\end{array}$ & 0,394 & 2.535 & $\begin{array}{c}\text { Tidak terjadi } \\
\text { multikolinearitas }\end{array}$ \\
\hline
\end{tabular}

Sumber: Data diolah (2019)

Pada tabel 3 di atas menunjukkan bahwa semua variabel independen mempunyai nilai tolerance $>0,10$ dan VIF $<10$. Dapat disimpulkan bahwa tidak ada kolerasi yang sempurna antar variabel independen sehingga model regresi ini tidak ada masalah multikolinearitas. 


\section{c. Hasil uji heteroskedastisitas}

Uji heteroskedastisitas dilakukan bertujuan untuk menguji apakah model regresi yang terjadi berbeda varians dari residual satu ke pengamatan yang lain. Model regresi yang baik apabila tidak mengandung heteroskedastisitas. Uji heteroskedastisitas bisa dilihat melalui grafik scatterplot.

Hasil uji heteroskedastisitas dapat dilihat pada gambar berikut:

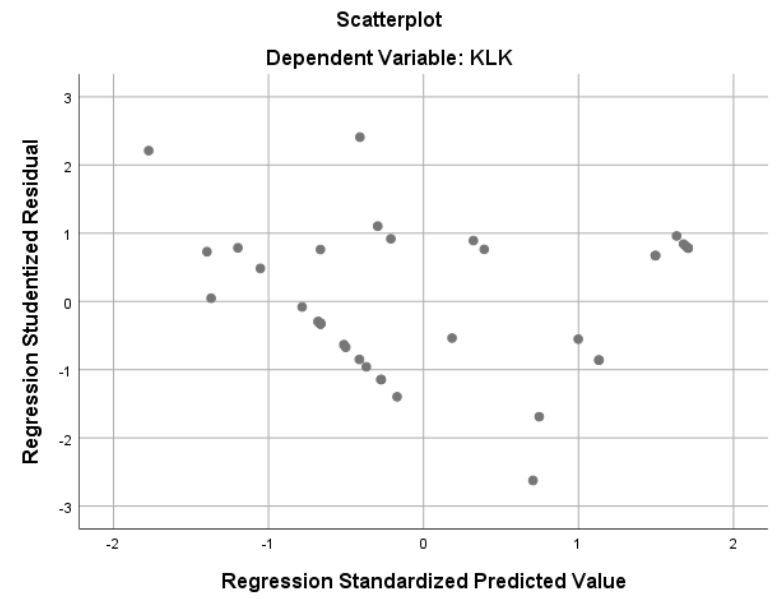

Gambar 1

Hasil Uji Heteroskedastisitas (Grafik Scatterplot)

Pada gambar 1 di atas menunjukkan titik-titik pada grafik scatterplot terlihat menyebar di atas dan di bawah angka 0 pada sumbu Y dan tidak ada pola yang jelas dari sebaran titik tersebut. Ini menunjukkan bahwa tidak terjadi heteroskedastisitas pada model regresi.

\section{Hasil Pengujian Hipotesis}

\section{a. Hasil analisis regresi linier berganda}

Analisis regresi linier berganda dilakukan untuk mengetahui pengaruh variabel independen terhadap variabel dependen. Analisis dilakukan dengan alat bantu program SPSS. Berikut ini tabel hasil analisis regresi linier berganda:

Tabel 4

Hasil Analisis Regresi Linier Berganda

\begin{tabular}{|c|c|c|c|c|c|c|}
\hline \multicolumn{7}{|c|}{ Coefficients $^{\mathbf{a}}$} \\
\hline & \multirow[b]{2}{*}{ Model } & \multicolumn{2}{|c|}{$\begin{array}{l}\text { Unstandardized } \\
\text { Coefficients }\end{array}$} & \multirow{2}{*}{$\begin{array}{c}\text { Standardized } \\
\text { Coefficients } \\
\text { Beta }\end{array}$} & \multirow[b]{2}{*}{$\mathrm{t}$} & \multirow[b]{2}{*}{ Sig. } \\
\hline & & $\mathrm{B}$ & Std. Error & & & \\
\hline \multirow[t]{4}{*}{1} & (Constant) & 9.680 & 3.538 & & 2.736 & .010 \\
\hline & $\mathrm{KSDMX}_{1}$ & -.057 & .116 & -.038 & -.490 & .627 \\
\hline & PSIADX $_{2}$ & .575 & .172 & .364 & 3.347 & .002 \\
\hline & $\mathrm{PSAPX}_{3}$ & .506 & .095 & .609 & 5.343 & .000 \\
\hline
\end{tabular}

a. Dependent Variable: KLKY

Sumber: Data diolah (2019) 
Berdasarkan tabel 4 di atas diketahui bahwa model regresi linear berganda adalah sebagai berikut:

$\mathrm{Y}=9680-0,057 \mathrm{X} 1+0,575 \times 2+0,506 \mathrm{X3}+\mathrm{e}$

Model regresi linear berganda di atas dapat dijelaskan sebagai berikut:

1. Nilai konstan Y sebesar 9,680 berarti jika variabel Kompetensi Sumber Daya Manusia $\left(\mathrm{X}_{1}\right)$, Penerapan Sistem Informasi Akuntansi Daerah $\left(\mathrm{X}_{2}\right)$, dan Penerapan Standar Akuntansi Pemerintahan $\left(\mathrm{X}_{3}\right)$ adalah 0 satuan, maka Kualitas Laporan Keuangan Pemerintah Daerah akan sebesar 9,680 .

2. Nilai koefisien $X_{1}$ sebesar $-0,057$ artinya apabila terdapat peningkatan variabel Kompetensi Sumber Daya Manusia sebesar 1 satuan sementara variabel independen lainnya tetap, maka Kualitas Laporan Keuangan Pemerintah Daerah akan mengalami penurunan sebesar 0,057.

3. Nilai koefisien $\mathrm{X}_{2}$ sebesar 0,575 artinya apabila terdapat peningkatan variabel Penerapan Sistem Informasi Akuntansi Keuangan Daerah sebesar 1 satuan sementara variabel independen lainnya tetap, maka Kualitas Laporan Keuangan Pemerintah Daerah akan mengalami peningkatan sebesar 0,575 .

4. Nilai koefisien $X_{3}$ sebesar 0,506 artinya apabila terdapat peningkatan variabel Penerapan Standar Akuntansi Pemerintahan sebesar 1 satuan sementara variabel independen lainnya tetap, maka Kualitas Laporan Keuangan Pemerintah Daerah akan mengalami peningkatan sebesar 0,506 .

\section{b. Hasil uji koefisien determinasi}

Uji koefisien determinasi ini berguna untuk memprediksi dan melihat seberapa besar kontribusi pengaruh yang diberikan variabel $\mathrm{X}$ secara simultan atau bersama-sama terhadap variabel Y. Hasil uji koefisien determinasi atau $r$ square dapat dilihat sebagai berikut:

Tabel 5

Hasil Uji Koefisien Determinasi Model Summary

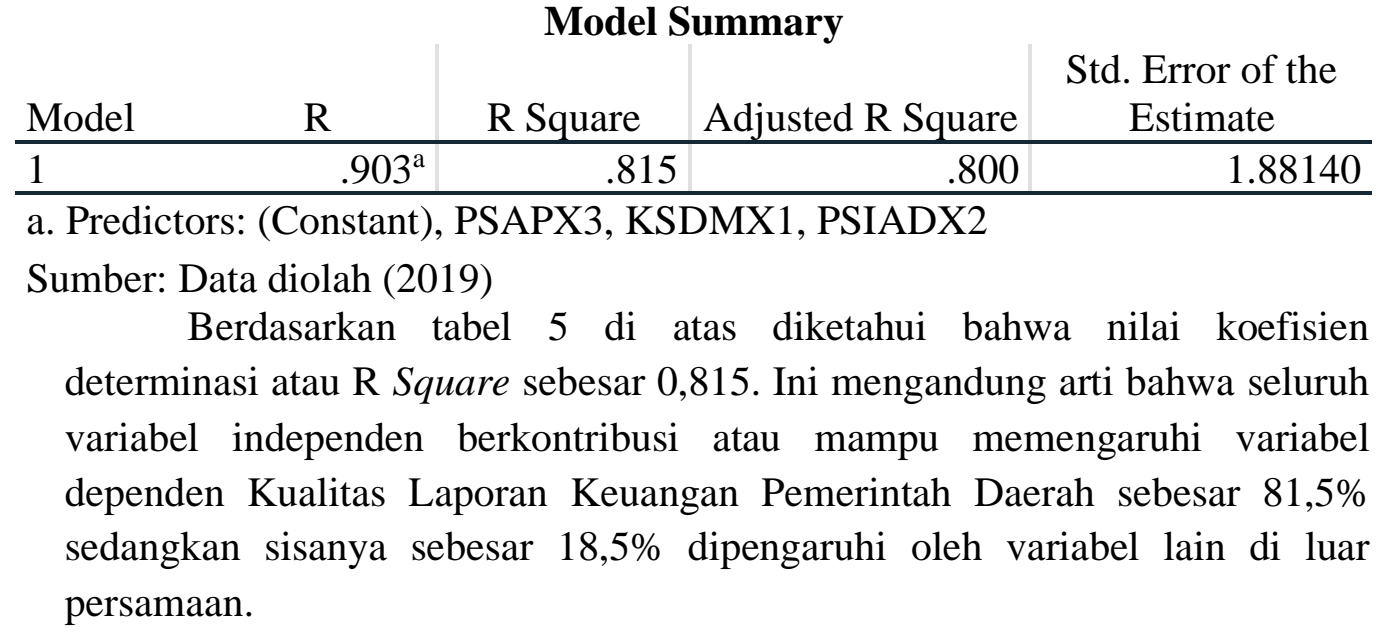




\section{c. Hasil uji t}

Uji $t$ dilakukan bertujuan untuk menguji pengaruh variabel independen secara parsial terhadap variabel dependen. Kriteria pengujian ditetapkan dengan tingkat signifikansi sebesar 5\%. Apabila nilai signifikansi pada hasil uji t menunjukkan nilai di atas 0,05 , maka dinyatakan pengaruh variabel independen secara parsial terhadap variabel dependen tidak signifikan. Hasil uji t dapat dilihat pada tabel berikut:

\section{Tabel 6}

Hasil Uji t

\begin{tabular}{|c|c|c|c|c|c|c|}
\hline \multirow{3}{*}{\multicolumn{2}{|c|}{ Model }} & \multicolumn{3}{|c|}{ Coefficients $^{\mathbf{a}}$} & \multirow[b]{3}{*}{$\mathrm{t}$} & \multirow[b]{3}{*}{ Sig. } \\
\hline & & \multicolumn{2}{|c|}{$\begin{array}{l}\text { Unstandardized } \\
\text { Coefficients }\end{array}$} & \multirow{2}{*}{$\begin{array}{c}\text { Standardized } \\
\text { Coefficients } \\
\text { Beta } \\
\end{array}$} & & \\
\hline & & $\mathrm{B}$ & Std. Error & & & \\
\hline 1 & (Constant) & 9.680 & 3.538 & & 2.736 & .010 \\
\hline & $\mathrm{KSDMX}_{1}$ & -.057 & .116 & -.038 & -.490 & .627 \\
\hline & PSIADX $_{2}$ & .575 & .172 & .364 & 3.347 & .002 \\
\hline & PSAPX $_{3}$ & .506 & .095 & .609 & 5.343 & .000 \\
\hline
\end{tabular}

a. Dependent Variable: KLKY

Sumber: Data diolah (2019)

Berdasarkan tabel 6 di atas diketahui bahwa hasil uji t untuk variabel Kompetensi Sumber Daya Manusia $\left(\mathrm{X}_{1}\right)$ diperoleh nilai sig. sebesar 0,627 lebih besar dari 0,05, maka ini memberi arti bahwa variabel Kompetensi Sumber Daya Manusia $\left(\mathrm{X}_{1}\right)$ tidak berpengaruh signifikan terhadap Kualitas Laporan Keuangan Pemerintah Daerah.

Sedangkan hasil uji $\mathrm{t}$ untuk variabel Penerapan Sistem Informasi Akuntansi Keuangan Daerah $\left(\mathrm{X}_{2}\right)$ diperoleh nilai sig. sebesar 0,002 lebih kecil dari 0,05, dan nilai konstanta sebesar 0,575, ini artinya variabel Penerapan Sistem Informasi Akuntansi Keuangan Daerah $\left(\mathrm{X}_{2}\right)$ berpengaruh positif signifikan terhadap Kualitas Laporan Keuangan Pemerintah Daerah.

Selanjutnya hasil uji t untuk variabel Penerapan Standar Akuntansi Pemerintahan $\left(\mathrm{X}_{3}\right)$ diperoleh nilai sig sebesar 0,000 lebih kecil dari 0,05, dan nilai konstanta sebesar 0,506, yang memberi arti variabel Penerapan Standar Akuntansi Pemerintahan $\left(\mathrm{X}_{3}\right)$ berpengaruh positif signifikan terhadap Kualitas Laporan Keuangan Pemerintah Daerah.

\section{d. Hasil uji F}

Uji $F$ dilakukan bertujuan untuk menguji pengaruh variabel independen secara simultan atau bersama-sama terhadap variabel dependen. Jika nilai sig. lebih kecil dari 0,05 maka dinyatakan semua variabel independen secara simultan berpengaruh signifikan terhadap variabel dependen. Hasil uji F dapat dilihat pada tabel berikut: 
Tabel 7

Hasil Uji F

\begin{tabular}{llr|r|r|r|r}
\hline \multicolumn{7}{c}{ ANOVA $^{\text {a }}$} \\
\hline Model & & Sum of Squares & \multicolumn{1}{c}{ df } & Mean Square & \multicolumn{1}{c}{ F } & \multicolumn{1}{c}{ Sig. } \\
\hline \multirow{2}{*}{1} & Regression & 562.947 & 3 & 187.649 & 53.013 & $.000^{\text {b }}$ \\
\cline { 2 - 7 } & Residual & 127.428 & 36 & 3.540 & & \\
\cline { 2 - 7 } & Total & 690.375 & 39 & & & \\
\hline
\end{tabular}

a. Dependent Variable: KLKY

b. Predictors: (Constant), PSAPX $_{3}, \mathrm{KSDMX}_{1}, \mathrm{PSIADX}_{2}$

Sumber: Data diolah (2019)

Berdasarkan tabel 7 di atas diketahui bahwa hasil uji $\mathrm{F}$ menunjukkan nilai sig. sebesar 0,000 lebih kecil dari 0,05 , ini berarti semua variabel independen secara bersama-sama berpengaruh signifikan terhadap variabel dependen.

\section{B. Pembahasan}

\section{Pengaruh Kompetensi Sumber Daya Manusia $\left(X_{1}\right)$ terhadap Kualitas Laporan Keuangan Pemerintah Daerah (Y)}

Dari hasil analisis regresi linier berganda menunjukkan bahwa Kompetensi Sumber Daya Manusia $\left(\mathrm{X}_{1}\right)$ tidak berpengaruh terhadap Kualitas Laporan Keuangan Pemerintah Daerah. Pemerintah Daerah Kota Sukabumi di satu sisi telah memiliki laporan keuangan yang berkualitas. Hasil temuan penulis di lapangan ketika mewawancarai responden menemukan bahwa mereka belum mendapatkan pelatihan akuntansi yang memadai. Ini menyebabkan masih belum optimalnya kompetensi mereka dalam bidang akuntansi. Hasil temuan lain dari penulis menemukan bahwa Pemerintah Daerah Kota Sukabumi menggunakan jasa mitra eksternal dalam menyelesaikan laporan keuangan. Boleh jadi telah berkualitasnya laporan keuangan Pemerintah Daerah Kota Sukabumi karena bantuan mitra eksternal tersebut, dengan kata lain bukan langsung oleh sumber daya manusia pemerintah daerah kota itu sendiri.

Kondisi seperti ini terjadi pula di Pemerintah Daerah Kabupaten Magelang, Provinsi Jawa Tengah, yaitu berdasarkan penelitian (Yuliani \& Agustini, 2016) yang menemukan bahwa Kompetensi Sumber Daya Manusia tidak berpengaruh terhadap Kualitas Laporan Keuangan Pemerintah Daerah (Yuliani \& Agustini, 2016).

2. Pengaruh Penerapan Sistem Informasi Akuntansi Keuangan Daerah $\left(\mathrm{X}_{2}\right)$ terhadap Kualitas Laporan Keuangan Pemerintah Daerah (Y)

Dari hasil analisis regresi linier berganda menunjukkan bahwa Penerapan Sistem Informasi Akuntansi Keuangan Daerah $\left(\mathrm{X}_{2}\right)$ berpengaruh positif signifikan terhadap Kualitas Laporan Keuangan Pemerintah Daerah. Hal ini sesuai dengan pernyataan bahwa laporan keuangan dihasilkan dari 
suatu proses yang didasarkan baiknya sistem layanan, kualitas sistem serta kualitas pengolahan informasi. Ketiga aspek tersebut berpadu dan berkesinambungan menjadi sebuah pondasi dalam sistem pengelolaan keuangan daerah. Dapat dibayangkan bagaimana jadinya apabila suatu instansi pemerintah tidak dapat memproses transaksinya secara jelas dan terpola dengan baik. Instansi pemerintah tersebut akan gagal mendapatkan informasi yang relevan dan dapat dipercaya yang diperlukan sebagai dasar dalam mengambil keputusan.

Hasil penelitian ini sejalan dengan penelitian yang dilakukan oleh (Herman \& Daswir, 2017) yang menemukan bahwa Penerapan Sistem Informasi Akuntansi Daerah berpengaruh positif signifikan terhadap Kualitas Laporan Keuangan Pemerintah Daerah (Herman \& Daswir, 2017).

3. Pengaruh Penerapan Standar Akuntansi Pemerintahan ( $\left.\mathrm{X}_{3}\right)$ terhadap Kualitas Laporan Keuangan Pemerintah Daerah (Y)

Dari hasil analisis regresi linier berganda menunjukkan bahwa Penerapan Standar Akuntansi Pemerintahan $\left(\mathrm{X}_{3}\right)$ berpengaruh positif signifikan terhadap Kualitas Laporan Keuangan Pemerintah Daerah. Penerapan Standar Akuntansi Pemerintahan berbasis akrual menyediakan informasi yang lebih lengkap dan terpercaya sehingga meningkatkan kredibilitas dalam mewujudkan transparansi serta akuntabilitas pengelolaan keuangan daerah.

Hasil penelitian ini sejalan dengan penelitian sebelumnya yang dilakukan oleh (Mahardini \& Miranti, 2018) yang menemukan bahwa Penerapan Standar Akuntansi Pemerintahan berpengaruh positif signifikan terhadap Kualitas Laporan Keuangan Pemerintah Daerah (Mahardini \& Miranti, 2018).

4. Pengaruh Kompetensi Sumber Daya Manusia $\left(X_{1}\right)$, Penerapan Sistem Informasi Akuntansi Keuangan Daerah $\left(\mathbf{X}_{2}\right)$, dan Penerapan Standar Akuntansi Pemerintahan $\left(X_{3}\right)$ secara bersama-sama terhadap Kualitas Laporan Keuangan Pemerintah Daerah (Y)

Dari hasil analisis regresi linier berganda menunjukkan bahwa ketiga variabel independen berpengaruh secara simultan terhadap Kualitas Laporan Keuangan Pemerintah Daerah. Besar pengaruhnya adalah 81,5\%. Hasil penelitian ini membawa implikasi bahwa untuk meningkatkan Kualitas Laporan Keuangan Pemerintah Daerah Kota Sukabumi dituntut untuk meningkatkan kompetensi sumber daya manusia, penerapan sistem informasi akuntansi keuangan daerah dan penerapan standar akuntansi pemerintahan di lingkungan kerjanya.

\section{Kesimpulan}

Kompetensi Sumber Daya Manusia tidak berpengaruh terhadap Kualitas Laporan Keuangan Pemerintah Daerah Kota Sukabumi. Pemerintah Daerah Kota Sukabumi telah memiliki laporan keuangan yang berkualitas, dibuktikan dengan raihan opini audit WTP dari BPK dalam lima tahun terakhir. Di sisi lain, Kompetensi Sumber 
Daya Manusia belum memadai akibat kurangnya pelatihan dalam bidang akuntansi. Saat ini dalam penyelesaian laporan keuangan, pemerintah daerah bekerjasama dengan mitra eksternal.

Penerapan Sistem Informasi Akuntansi Keuangan Daerah berpengaruh positif signifikan terhadap Kualitas Laporan Keuangan Pemerintah Daerah Kota Sukabumi. Hal ini sejalan dengan pernyataan bahwa laporan keuangan dihasilkan dari suatu proses yang didasarkan sistem layanan, kualitas sistem serta kualitas informasi.

Penerapan Standar Akuntansi Pemerintahan berpengaruh positif signifikan terhadap Kualitas Laporan Keuangan Pemerintah Daerah. Telah diterapkannya dengan baik Standar Akuntansi Pemerintahan di lingkungan Pemerintah Daerah Kota Sukabumi meningkatkan kredibilitas laporan keuangan pemerintah daerah dalam mewujudkan transparansi dan akuntabilitas pengelolaan keuangan daerah.

Ketiga variabel independen berpengaruh secara simultan terhadap Kualitas Laporan Keuangan Pemerintah Daerah. Besar pengaruhnya adalah 81,5\% sedangkan sisanya sebesar $18,5 \%$ dipengaruhi oleh variabel lain di luar penelitian ini. 


\section{BIBLIOGRAFI}

Arikunto, S. (2016). Prosedur Penelitian Suatu Pendekatan Praktis. PT Rineka Cipta.

Briando, B. (2017). Desentraliasi Fiskal Desa. Assets: Jurnal Akuntansi Dan Pendidikan, 6(2), 93-106.

Edy Sutrisno, Widhi Novianto, Ani Suprihartini, R. S., \& Rita Dwi KU, M. D. P. (2015). Telaahan Isu-isu Strategis Desentralisasi Dan Otonomi Daerah. Pusat Kajian Desentralisasi dan Otonomi Daerah.

Eriotis, N., Stamatiadis, F., \& Vasiliou, D. (2011). Assessing accrual accounting reform in Greek public hospitals: an empirical investigation. International Journal of Economic Sciences and Applied Research, 4(1), 153-183.

Erviana. (2017). Pengaruh Implementasi Sistem Informasi Manajemen Daerah dan Kegiatan Terhadap Kualitas Laporan Keuangan Pemerintah Daerah. Jurnal Katalogis, 5(4), 182-193.

Herman, L. A., \& Daswir, D. (2017). Factors Analysis Of Affecting The Quality Of Government Finance Subsidiaries (Empirical Study Payakumbuh Government). Jurnal Pundi, 1(2).

Indonesia, P. R. (2004). Undang-undang republik indonesia nomor 1 tahun 2004 tentang perbendaharaan negara.

Indonesia, P. R. (2010). Peraturan Pemerintah Nomor 70 tahun 2010 tentang Standar Akuntansi Pemerintahan.

Indonesia, P. R. (n.d.). Undang-Undang Republik Indonesia Nomor 23 Tahun 2014 tentang Pemerintahan Daerah.

Khalid, H. \&. (2016). Pengaruh Kompetensi Sumber Daya Manusia dan Pemanfaatan Teknologi Informasi terhadap Kualitas Laporan Keuangan dengan Sistem Pengendalian Intern Sebagai Variabel Moderasi pada SKPD Kabupaten Polewali Mandar. Jurnal Akuntansi Peradaban, 1(1).

Lasoma, V. A. (2013). Pengaruh Standar Akuntansi Pemerintahan Terhadap Kualitas Laporan Keuangan Pemerintah Daerah. Jurnal Akuntansi Dan Manajemen, 1(1).

Lusiawati, I. (2020). Reformasi Birokrasi Dalam Organisasi Kemahasiswaan Universitas Kebangsaan Bandung. Syntax Literate; Jurnal Ilmiah Indonesia, 5(2), $75-82$.

Mahardini, N. Y., \& Miranti, A. (2018). Dampak Penerapan Standar Akuntansi Pemerintahan dan Kompetensi Sumber Daya Manusia pada Kualitas Laporan Keuangan Pemerintah Provinsi Banten Tahun Anggaran 2015. JAK (Jurnal Akuntansi): Kajian Ilmiah Akuntansi, 5(1), 22-32. 
Munawir, S., Keuangan, A. L., Keempat, E., \& Kelimabelas, C. (2010). Liberty Yogyakarta. Yogyakarta.

Roviyantie, D. (2011). Pengaruh kompetensi sumber daya manusia dan penerapan sistem akuntansi keuangan daerah terhadap kualitas laporan keuangan daerah. Skripsi. Universitas Siliwangi.

Sari, S. P., \& Witono, B. (2014). Keterandalan dan ketepatwaktuan pelaporan keuangan daerah ditinjau dari sumber daya manusia, pengendalian internal dan pemanfaatan teknologi informasi.

Sugiyono. (2017). Metode Penelitian Kuantitatif, Kualitatif, dan R\&D. CV. Alfabeta.

Yuliani, N. L., \& Agustini, R. D. (2016). Faktor yang mempengaruhi kualitas laporan keuangan pemerintah daerah. Jurnal Analisis Bisnis Ekonomi, 14(1), 56-64.

Zelmiyanti, R. (2016). Pendekatan Teori Keagenan pada Kinerja Keuangan Daerah dan Belanja Modal (Studi pada Provinsi di Indonesia). JRAK: Jurnal Riset Akuntansi Dan Komputerisasi Akuntansi, 7(1), 11-21. 